\title{
IMPORTANCE OF EMPLOYEE'S MOTIVATION FOR BUSINESS SUCCESS - EXAMPLE OF BEIERSDORF
}

\author{
Jelena Teodorović ${ }^{1 *}$ \\ Slađana Čabrilo²
}

${ }^{1} \mathrm{PhD}$ candidate,Singidunum University, Belgrade, Serbia ${ }^{2}$-Shou University, Kaohsiung/ Taiwan, The People's Republic of China

\begin{abstract}
:
Employees are one of the company's most important resources. In order to build a good relationship with employees, managers must motivate them. Motivation can be described as a set of factors that drive people and direct them to meet certain needs. Many authors have written about this concept by developing various theories. One of the most famous motivation theories is Maslow's need hierarchy. In addition to this, there are other, generally accepted theories, such as theories $\mathrm{X}$ and $\mathrm{Y}$, the equity theory or expectancy theory. Although the authors disagree with that what motivates people, they share the common view that employee motivation is the key to company's success. Due to importance of human resources in modern business, the subject of the analysis in this paper is the influence of motivation on the business success. We analyzed Beiersdorf management practise and the way it motivates employees.
\end{abstract}

\section{Keywords:}

human resources, employee motivation, motivation theory, employee loyalty

\section{INTRODUCTION}

Every company wants to be recognized on the market and to be profitable. To succeed in this, it must have adequate resources, and employees represent one of the most important resources. If a company wants to be successful and competitive, it is necessary to have valuable and loyal employees. For employees to be productive, engaged to the highest extent and in order to reduce their fluctuation, they must be motivated. Only with appropriate motivation strategies, the companies can develop a positive relationship with their employees, based on mutual trust and the desire of employees to stay in it. Having seen the significance of this topic, many authors, while trying to explain the notion of motivation, have developed different motivation theories. As the times changed, theories developed and upgraded.

\section{LITERATURE REVIEW}

The word "motivation" derives from the Latin word "movere", which means move, start. Motivation is a process that corresponds to the intensity, direction and persistence of an individual towards achieving goals (Robbins \& Judge, 2013). It is the driving force by which people achieve their goals, needs and values (Mullins, 2010). It is a set of forces that cause people to focus on one goal rather than an alternative one (Steers, Bigley \& Porter, 2002). Motivation can be described as a set of factors that direct and drive people to achieve their goal (Campbell \& Pritchard, 1976). It is a psychological characteristic of people that affects the level of their commitment (Čerović, 2012). In the business world, motivation is explained as a desire to do something (Cambridge Advanced Learner's Dictionary, 2008). 
One of the first authors to have written about work motivation, Frederick Taylor, believed that people were economically motivated and would work to earn as much as possible. The only motivator in this case was money (Taylor, 1911). In the 1930s the theory was developed that people have strong social needs and want to feel useful, and that this is a stronger motivator for them than money. In the coming decades this theory has been upgraded and modern theories of motivation are being developed (Moorehead \& Griffin, 2010).

The most famous theory of motivation is Maslow's hierarchy of needs. Maslow believes that every living being has needs, which he classifies in five levels (physiological needs, needs for security (safety), social needs, the need for respect, the need for self-actualization), as shown on Figure 1. According to him, in order to motivate somebody, we need to know at what level of needs that person is right now and to try to satisfy the need of a higher rank (Maslow, 1943).

Figure 1Maslow's hierarchy of needs

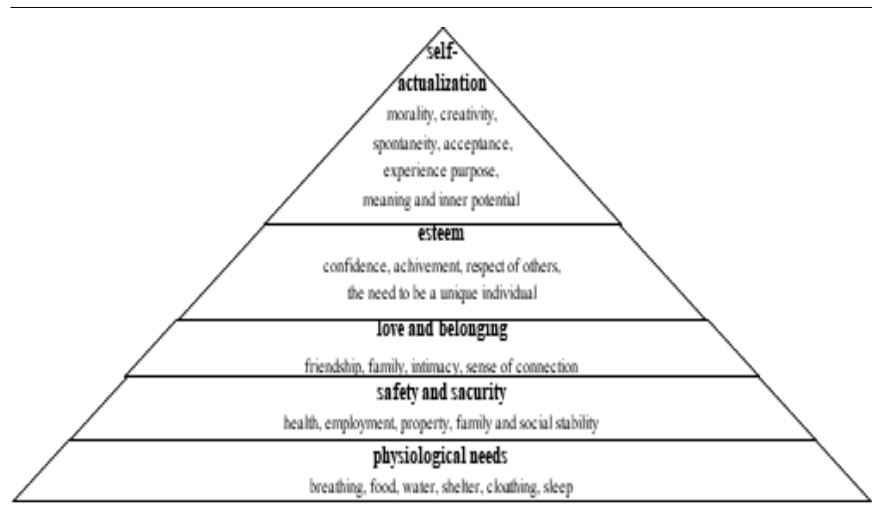

Source: Maslow, A. H. (1943). A theory of human motivation. Psychological review, 50(4), 370

By modeling this theory, Alderfer exposes his ERG theory. According to him, there are three levels of needs: existential, need for connectivity and development needs (Mullins, 2010). Unlike Maslow, Adlerfer argues that it's not necessary to first meet the needs of the lower level, in order to meet the needs of the higher one. Furthermore, he states that at the same time it's possible to satisfy more needs. McClelland, on the other hand, states that employees develop the needs for achievement, needs for power and needs for connection (McClelland, 1965).

Trying to explain the motivation and the ways to motivate employees, Douglas McGregor exhibits two theories, Theory $\mathrm{X}$ and Theory Y. The starting point of Theory $\mathrm{X}$ is that employees don't like work and they will avoid it whenever possible, so managers need to force, control and punish them, in order to complete their job. On the other hand, according to Theory Y, it's considered that this opinion is outdated and that employees can experience work as something completely natural.
They can accept and even seek to undertake responsibility. According to this theory, employees will dedicate themselves to work, as much as they'll be rewarded for it (McGregor, 1960). On the other hand, Nord points out that Theory $\mathrm{Y}$ is a reflection of what managers feel and speak about, and what they really do (Nord, 1978).

Believing that motivation has a significant impact on the individual's performance, and thus on the business success of one company, Frederick Herzberg refferes to the theory of two factors.By examining the employees, he makes them write in detail what is what makes them feel good in their business, and what is why they feel bad. Thus, it comes to the conclusion that there are factors that affect the ultimate satisfaction, or dissatisfaction. Those factors that influence satisfaction can be defined as internal (progression, recognition, responsibility). Dissatisfaction, on the other hand, is influenced by external factors, such as pay, supervision, working conditions or company policy (Robbins \& Judge, 2013). This is one of the most poorly accepted motivation theories, precisely because of the subjectivity of the respondents (Mullins, 2010).

Victor Vroom developed a theory of expectations, stressing that employees are most motivated when they know that their greater commitment will lead to better performance, and thus to a better outcome (Vroom, 1964). A motivated employee becomes loyal, and a loyal employee supports the company's goals and works to fulfill them. A motivation is necessary to maintain optimism in a company (Griffin \& Moorhead, 2013).

According to the theory of equality, the people will be motivated when they learn they are treated fairly. It relates to a subjective assessment of an individual on the fairness of the reward received for contributions, in comparison with the prizes of others (Uzonna, 2013).Workers compare among each otherwhat they receive for their hard work. They can compare their efforts with the efforts of other employees who perform a different job within the same company, then their efforts with the efforts of other employees who do the same job in another company, or their efforts with efforts of other employees who do the same job in the same company.

According to goal setting theory, people are motivated to the extent that they get clear goals, but they have to have feedback on their performance, in terms of achieving these goals (Locke \& Latham, 1990).Setting goals can reduce stress and increase employee motivation. Also, the higher the goals are, the greater perseverance of the employees will be, which affects the better performance of tasks and leads to the business success of the companies (Langton, Robbins \& Judge, 2013).

According to the theory of support, managers need to reward or penalize their employees thereby affecting their motivation to work, because it will stabilize the behavior 
that has been rewarded, while the behavior followed by penalties will eventually be eliminated. (Williams, 2010)

None of these theories alone is sufficient to ensure the long-term motivation of employees. Since motivating is a management process, which affects the behavior of employees (Čerović, 2012), it's very important for managers to discover what is that thing that can motivate each individual employee and to implement in their organizations the so-called integrated model of motivation, thus directing its employees to the implementation of company goals facilitating in that way achievement of business success (Williams, 2010).

While it's easy to say that motivation is what drives people, it's not easy to implement it in practice. According to research conducted by company Creative Group, nearly one-third of respondents in the management responded that motivating employees is their most difficult task (Williams, 2010). One of the reasons is that according to the theories of motivation divided opinions, what is actually what motivates people. Motivation can be material and intangible, intrinsic (internal) or extrinsic (external), that is, motivators can be different. What motivates and drives an employee, does not necessarily havean influence on the other person. One employee can be motivated by money, while the other can be motivated by the satisfaction with the job, or by the sense of fulfillment of the completed task. In other words, everything depends on the person, that is, the worker himself (Frey \& Osterloh, 2001).

One of the most common motivators, of course, is money, but non-material motivationis also very important. According to the survey, even 94\% of employees consider that non-material incentives and rewards can greatly affect their motivation. In addition, the compliments, or simply expressed Thanks, greatly raise the morale of the workers and their commitment to work. It has been shown that other factors, such as job security, diversity and interesting job, the possibility of independent decision making, attendance of different trainings, can be equally important for the motivation of employees (Uzonna, 2013). This can affect the fact that workers feel more important to the company and that their work is significant and therefore make more effort, which leads to higher productivity, effectiveness and efficiency of the entire company (Bulatović, Đurašević \& Stranjančević, 2016).

That is why it's a difficult task for managers to choose and implement a proper motivation system within a company. One of the key roles of managers is to motivate their employees. A good incentive program, as well as, motivated employees, greatly affect the company's performance and its greater efficiency (Uzonna, 2013). Since acquiring knowledge and improving new skills is essential for business success, companies need to have motivated employees who will willingly work and carry out their tasks.Since competence of employees is one of the company's resources, and the one that competitors can hardly imitate, it's necessary for the company to have loyal workers, thereby reducing the fluctuation of the workforce, and this isn't possible if they aren't motivated (Balje,2016). Therefore, it can be said with certainty that employee motivation is the key to the business success of the company.

However, the motivation for the job and the readiness to acquire new knowledge and skills, achieving better performance, as well as greater efficiency of the company depends on the support that the employees receive at their workplace (Bulatović, Đurašević \& Stranjančević, 2016).Motivation isn't a simple concept. It refers to different instincts, desires and needs.Managers motivate by providing an environment that encourages members of the organization to make their contribution, precisely trying to satisfy the wishes and needs of their workers (Uzonna, 2013). Because people are motivated by needs that aren't met, the managers need to find out what are that needs and to respond to them, in order to motivate their employees. The directing of employees to do their job, even when it's very demanding, is possible if they're well motivated (Manzoor, 2012).The motivation of employees is one of the policies of managers to increase effectiveness. The manager should know how to direct his employees' efforts in the best possible way, to achieve the goals of the organization (Mullins, 2010). The motivation is vital for all organizations. Research shows that motivation plays a key role in predicting performance (Locke, 2009). Often the difference between highly efficient organizations and those less efficient lies precisely in the motivation of their members. Therefore, managers must understand the nature of individual motivation, or what motivates each employee individually (Moorehead \& Griffin, 2010). In order to achieve a high level of performance and thus directly affect the performance of the company, each employee must have, in addition to the appropriate ability to perform tasks and environments in which he can perform his tasks, also a certain level of motivation for his job (Pfeiffer, 1998).

$$
\mathrm{P}=\mathrm{M}+\mathrm{A}+\mathrm{E}(1)
$$

$\mathrm{P}$ - performance

$\mathrm{M}$-motivation

A - ability

E- environment

\section{METHODOLOGY}

For the purposes of the paper, a survey was carried out in June 2019 in the Beiersdorf. It's an international company based in Germany, and for the needs of this paper we've examined the employees in Serbia, i.e. in Belgrade. Sixteen employees were surveyed, which makes up a third of employees. 
We were interested in the following:

- What motivates them at work;

- Are they satisfied with the company's motivation system;

- Do they feel safe working for this company;

- Would they leave this company for another which does not have a developed system of motivation for a slightly higher salary $(30 €)$.

In addition to the survey, an interview with employees was also conducted, where they were asked more thoroughly about the system of motivation in the company and their satisfaction.

\section{RESULTS AND DISCUSSION}

The results obtained by this study have confirmed that motivation is one of the most important management activities. Without a well-designed motivation program in one organization, it can't be expected that employees will turn to achieving results.

According to the research, employees of Beiersdorf are motivated by different things, as shown on Chart 1 . Although motivated by money, immaterial stimulants are prevalent, such as good interpersonal relations that govern the company (81\%) and the possibility of professional training in the areas of interest (69\%). The training opportunity is the strongest motivator for younger people. As much as $91 \%$ of employees under the age of 40 declared themselvesthis way.

In addition, employees are influenced by intrinsic motivation.Over half of the employees (56\%) point out that the feeling of fulfillment is one of the main drivers for work. It's interesting that intrinsic motivation is a stronger driver for younger people. Namely, even two thirds of employees under the age of 40 believe that internal motivation is the most important for their work and business results.

Money as a stimulant is important for $44 \%$ of employees. Interestingly, money is more important to those employees whose source of income isn't the principal, or the only one in the families. Even $71 \%$ of employees consider that their income isn't the main (only) in the family, and on the other hand they consider that money is one of the factors that motivate them most. In addition, money is a weaker motivator for employees who have children, compared to those who don't have any, $43 \%$ to $57 \%$.

The existence of various benefits also represents a good motivator. Through interviews with employees, we concluded that the most important benefits that this company uses to motivate its employees is private health insurance, free foreign language learning and the possibility of free everyday recreation. The possibility of free private health insurance for employees and their family members is most important for employees with small children.

It is interesting that a good relationship between business and private life is a stronger motivation for employees who don't have children. Namely, only a third of workers, who find this an important motivator, have children.

It's also interesting that praise by superiors isn't a strong motivator in this company. Only $31 \%$ of employees believe that this is what influences their motivation, of which $80 \%$ is less than 40 years old, $60 \%$ are female and $40 \%$ male.

A quarter of the respondents think that they're motivated by the possibility of career advancement in their work. Expectedly, all who have marked this factor as a strong motivator, are younger than 40 years old.

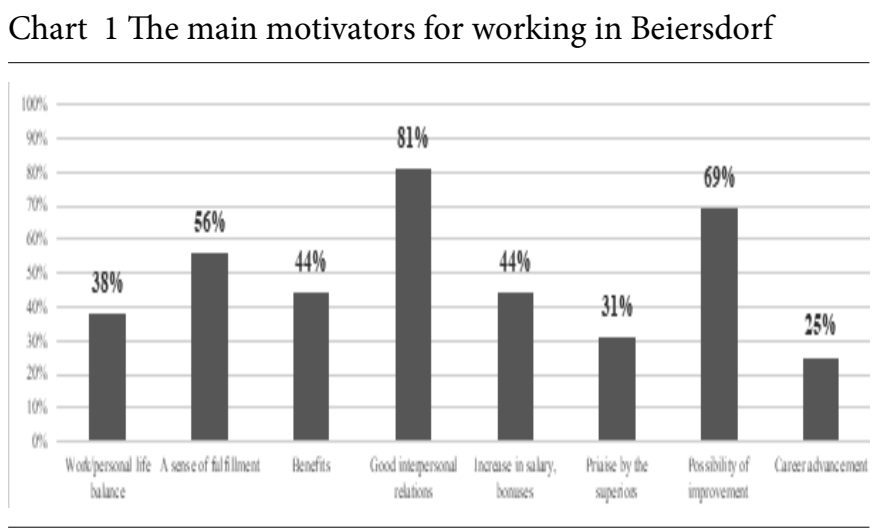

Each company should have a well-developed system of motivation for its employees. According to research results, $100 \%$ of Beiersdorf employees are satisfied (of which $12.5 \%$ are very satisfied) with the system of motivation in the company, which directly affects their loyalty and commitment (Chart 2). A good overall motivation system for employees is more important than the level of earnings. Money, although a good motivator, isn't enough to make employees decide to change the company in which they work, as shown in Chart 3. Even $81 \%$ of employees would certainly not go to another company that doesn't have a developed system of motivation, if they were offered a slightly higher salary (30€). In addition, also the remaining 19\% would probably not accept another job under these conditions. This shows that employee motivation doesn't have to be a cost to the company. On the contrary, if good interpersonal relations are prevailing, optimism develops throughout the organization and employees feel more connected with the company, which increases their commitment and desire for success, both their own and the success of the whole company. 
Chart 2 Employee satisfaction with the company's motivation system

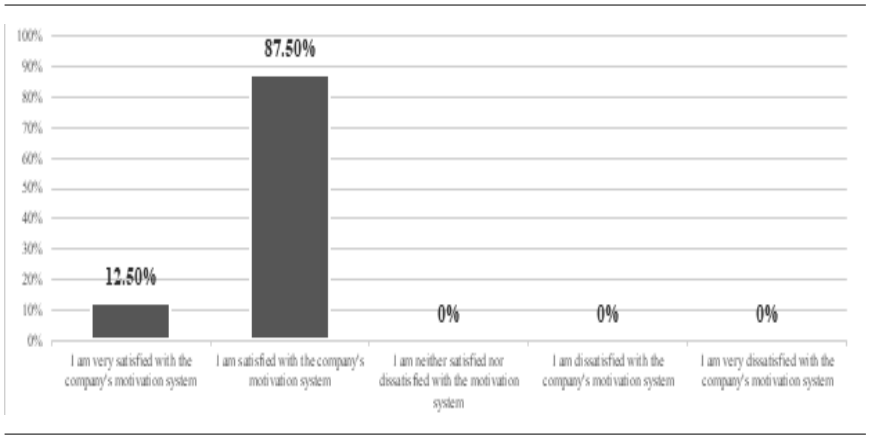

Chart 3 The impact of motivation on employee loyalty

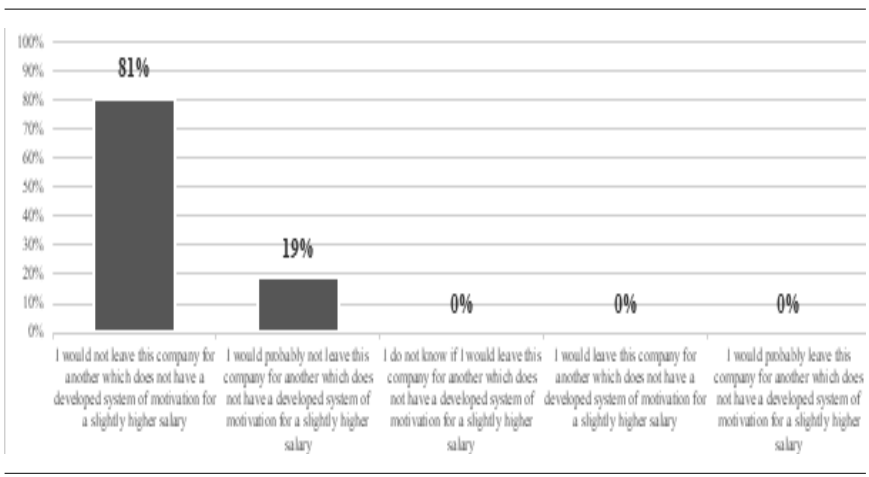

With this research we came to the conclusion that motivation plays a key role in engaging in work. How much the employees are eager to work on themselves, to improve themselves and to achieve the results, depends primarily on how motivated and focused they are. One of the most important motivators is certainly a sense of security. If workers feel safe in the company, they'l think about it as their second home and will do everything to achieve positive results. Employees (i.e. 69\% of them) see Beiersdorf as a company in which they feel safe and this sense of security has an effect of a very strong motivator on them (Chart 4).

\section{Chart $4 \mathrm{~A}$ sense of security due to work forBeiersdorf}

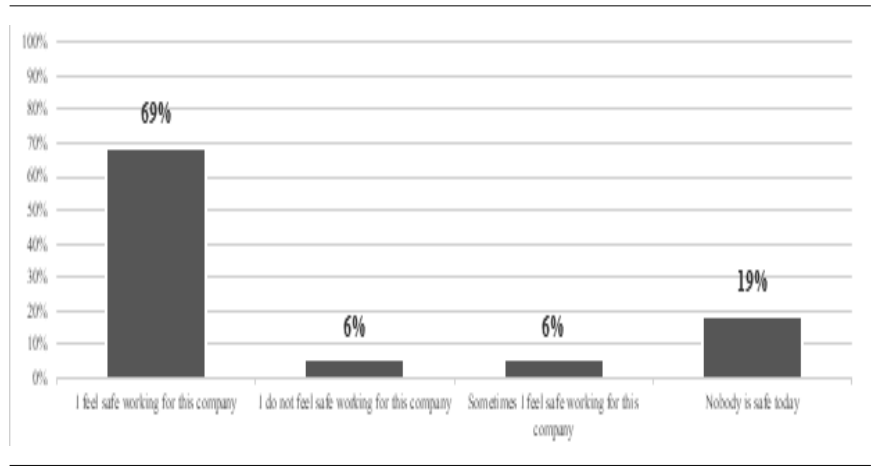

In support of how important the motivation is for this company, there is the fact that an employee satisfaction survey is carried out annually. This research is carried out all over the world, and the results are obtained both collectively and individually for each country or region. Here, employees can express their sincere opinions, with- out fear that what they say would have a negative effect on them. When all the answers are collected, the results are presented to the managers and they're obliged to act in order to correct all that turned out to be negative in the previous period.

In addition, through interviews with employees, we concluded that employees perceive the Beiersdorf as a company that cares about them and feel themselves as an important member. Likewise, they feel security working in a company that is long lasting and stable. They share company values and believe that the company is their second home. The fact that payroll payments are regular and fair and that what is agreed is honoured, positively influences their attitudes and desire for further work. The existence of clear procedures makes it easier to work and achieve good results. In addition, it's extremely important to employees that they can and that they are motivated to state their opinion, knowing that it will always be respected when there're grounds for that. All these together influence how good they feel working in this company and gives them motivation for further work and success.

\section{CONCLUSION}

Many authors have written about motivation and its importance to the business success of the company. The motivation is necessary in order to maintain optimism in the company and in order to focus employees on achieving goals. Based on the literature analyzed, we can conclude that the motivation is one of the most important management activities in each organization. It affects the overall picture that employees perceive about a company. If the company does not have optimism and good interpersonal relationships, it greatly affects the attitudes of each individual employee. This can further affect the loss of interest and the desire to improve, learn, make effort and result in them leaving the organization. In order for a company to preserve its most important resource, its employees, it must attract and interest them to work, it must motivate them. Only organizations with a strong, well-organized motivation system can be recognized on the market as organizations in which employees want to work and achieve the results.

The research confirmed that although money is a strong motivator, in the modern era organization has a more prominent system of non-material motivation. And not for the sake of cost reduction, but because even for the employees themselves, non-material stimulants can have a much greater effect than money. The sense of security and the knowledge that the management takes care of them, creates in the employees the will to work and the desire to direct their forces to achieving business results. In addition, this feeling affects employees feeling privileged by 
working in a company that cares about them and there is a sense of belonging and loyalty to it. Although employee motivation is a complex process and there is no one generally accepted motivation theory, it can be concluded from research that Vroom's theory of expectations works best for Beiersdorf.

The research has shown that Beiersdorf takes a permanent care of its employees. Although its an international company, which operates in the Republic of Serbia, this is a good basis for creating new HR trends in our market. If other companies want to be successful, they must apply modern trends, in order not to lose their employees.

\section{LITERATURE}

1. Balje, D. J. (2016). Uticaj ljudskog kapitala na stvaranje održive konkurentske prednosti u poslovanju savremenih organizacija (Doctoral dissertation, Univerzitet Edukons, Fakultet poslovne ekonomije).

2. Bulatović, I., Đurašević, S., \& Stranjančević, A. (2016). Human resources as a factor of competitiveness and quality in the hospitality industry. In SITCON-Singidunum International Tourism Conference, Belgrade, Serbia.

3. Campbell, J. P., \& Pritchard, R. D. (1976). Motivation theory in industrial and organizational psychology. Handbook of industrial and organizational psychology, 1(63), V130.

4. Čerović, S. (2013). Upravljanje ljudskim resursima u hotelijerstvu. Beograd: Fakultet za turistički i hotelijerski menadžment, Univerzitet Singidunum.

5. Frey, B. S., \& Osterloh, M. (Eds.). (2001). Successful management by motivation: Balancing intrinsic and extrinsic incentives. Springer Science \& Business Media.

6. Griffin, R. W., \& Moorhead, G. (2013). Organizational behavior. Nelson Education.

7. Langton, N., Robbins, S. P., \& Judge, T. A. (2013). Fundamentals of organizational behaviour. Pearson Education Canada.

8. Locke, E. A. (2009). Handbook of principles of organizational behavior.

9. Locke, E. A., \& Latham, G. P. (1990). A theory of goal setting \& task performance. Prentice-Hall, Inc.

10. Manzoor, Q. A. (2012). Impact of employees motivation on organizational effectiveness. Business management and strategy, 3(1), 1-12.

11. Maslow, A. H. (1943). A theory of human motivation. Psychological review, 50(4), 370.

12. McClelland, D. C. (1965). Toward a theory of motive acquisition. American psychologist, 20(5), 321.

13. McGregor, D. (1960). The human side of enterprise (Vol. 21, No. 166-171). McGraw-Hill: New York.

14. Moorehead, G., \& Griffin, R. W. (2010). Organizational behavior: Managing people and organizations. SouthWestern/Cengage Learning.
15. Mullins, L. J. (2010). Management and organisational behaviour. Pearson education.

16. Nord W. (1978) „Theory Y assumptions in non-Theory $Y$ world“, Interfaces, Vol.8, No.2. pp. 61-66.

17. Pfeiffer J. (1998). The Human Equation Boston: Harvard Business School Press.

18. Richard M. Steers, Gregory A. Bigley, and Lyman W. Porter (2002), Motivation and Leadership at Work,7th ed. New York: McGraw-Hill.

19. Robbins, S. P., \& Judge, T. A. (2013). Organizational Behavior. By Pearson Education. Inc., Upper Saddle River, New Jersey.

20. Taylor F. W. (1911), Principles of ScientificManagement. New York: Harper.

21. Uzonna, U. R. (2013). Impact of motivation on employees performance: A case study of Credit West Bank Cyprus. Journal of Economics and International Finance, 5(5), 199-211.

22. Vroom, V. H. (1964). Work and motivation (Vol. 54). New York: Wiley.

23. Williams, C. (2010) MGMT: Principles of management, Data Status, Belgrade

24. Walter, E. (2008). Cambridge advanced learner's dictionary. Cambridge University Press. 